\title{
ISTRAŽIVANJE ODNOSA UPRAVLJAČKIH STRUKTURA I EKSTERNE REVIZIJE U KORPORATIVNOM UPRAVLJANJU **
}

Kvalitetna komunikacija eksternih revizora s upravljačkim strukturama od iznimne je važnosti za učinkovito poslovanje kreditnih institucija. Stoga se nameće pitanje može li se oblikovanjem modela odnosa eksternih revizora i upravljačkih struktura kreditne institucije unaprijediti rad eksterne revizije, s jedne strane te upravljačkih struktura kreditne institucije, s druge strane. Doprinos ovog istraživanja su: analiza kvalitete komuniciranja eksternih revizora s upravljačkim strukturama kreditne institucije i utjecaj kvalitete tih odnosa na učinkovitost eksterne revizije i upravljačkih struktura; analiza kvalitete komuniciranja eksternih revizora s revizijskim odborom kreditne institucije $i$ utjecaj kvalitete tih odnosa na učinkovitost eksterne revizije $i$ upravljačkih struktura, posebice nadzornog odbora; identificiranje je li neučinkovitost eksterne revizije povezana s otvaranjem stečajeva nad kreditnim institucijama i utvrđivanje pridonosi li predloženi model odnosa eksternih revizora i upravljačkih struktura kreditne institucije boljem radu eksterne revizije kao i boljem radu upravljačkih struktura kreditne institucije. U istraživanju, provedenom u Republici Hrvatskoj, sudjelovali su eksterni revizori koji obavljaju ili su obavljali reviziju godišnjih financijskih izvještaja kreditnih institucija, članovi uprave i nadzornih odbora kreditnih institucija te

* M. Filipović, dr.sc., BDO Hrvatska d.o.o. (e-mail: mario.filipovic@bdo.hr). Rad je primljen u uredništvo 13.02.2019. godine, a prihvaćen je za objavu 02.04.2019. godine.

*** Rad se temelji na istraživanju doktorske disertacije obranjene u akademskoj godini 2018./2019. te je prilagođen objavi u časopisu kako bi se rezultati istraživanja stavili na raspolaganje široj znanstvenoj i stručnoj javnosti. 
M. FILIPOVIĆ: Istraživanje odnosa upravljačkih struktura i eksterne revizije u korporativnom upravljanju EKONOMSKI PREGLED, 72 (4) 522-549 (2021)

stečajni upravitelji i stručno osoblje kreditnih institucija u stečaju. Rezultati empirijskog istraživanja potvrđuju kako testirani komunikacijski model pridonosi učinkovitijem radu eksterne revizije i upravljačkih struktura kreditne institucije.

Ključne riječi: kvaliteta komuniciranja, eksterni revizori, upravljačke strukture, kreditna institucija

\section{UVOD}

Uloga kreditnih institucija u kontekstu gospodarskog razvoja je neupitna (Basu, 2007:171). Stoga je izuzetno bitno zdravlje svakoga bankovnog sustava, posebice kreditnih institucija kao njegove okosnice. Nepoželjni scenariji, koji se ogledaju u pokretanju stečajnih odnosno likvidacijskih postupaka kreditnih institucija, trebaju biti pravodobno spriječeni. U tom smislu važnu ulogu imaju eksterna revizija i upravljačke strukture kreditnih institucija. Kako bi eksterna revizija mogla svojim djelovanjem pravodobno upozoriti na loše poslovne scenarije bitno je da imaju dobru komunikaciju s upravljačkim strukturama kreditnih institucija. Uza sve navedeno kvalitetno komuniciranje, koje se temelji na odgovarajućem komunikacijskom modelu sastavljenom od više njegovih komponenti, može pridonijeti učinkovitijem radu eksternih revizora i upravljačkih struktura kreditnih institucija. Upravo je oblikovanje modela komuniciranja između eksternih revizora i upravljačkih struktura kreditnih institucija i njegovo testiranje glavna namjena ovoga rada. Bolji rad eksterne revizije i upravljačkih struktura kreditne institucije, koji bi bio posljedica jednog takvog komunikacijskog modela, ne samo što bi izravno prevenirao potencijalne probleme koji bi mogli ugroziti održivost tih poslovnih subjekata, već bi učinkovitiji rad svih navedenih sudionika toga modela otvorio prostor za uspješnije poslovanje kreditnih institucija.

Ciljevi ovog istraživanja su: analizirati kvalitetu komuniciranja eksternih revizora s upravljačkim strukturama kreditne institucije i utjecaj kvalitete tih odnosa na učinkovitost eksterne revizije i upravljačkih struktura; analizirati kvalitetu komuniciranja eksternih revizora s revizijskim odborom kreditne institucije i utjecaj kvalitete tih odnosa na učinkovitost eksterne revizije i upravljačkih struktura, posebice nadzornog odbora; utvrditi je li neučinkovitost eksterne revizije povezana s otvaranjem stečajeva nad kreditnim institucijama i utvrditi pridonosi li predloženi model odnosa eksternih revizora i upravljačkih struktura kreditne institucije boljem radu eksterne revizije kao i boljem radu upravljačkih struktura kreditne institucije. 
Na osnovi definiranih ciljeva istraživanja, razvijene su sljedeće hipoteze:

H1: Kvaliteta komuniciranja eksternih revizora s upravljačkim strukturama kreditne institucije utječe na učinkovitost eksterne revizije i upravljačkih struktura.

H2: Kvaliteta komuniciranja eksternih revizora s revizijskim odborom kreditne institucije utječe na učinkovitost eksterne revizije i upravljačkih struktura, posebice nadzornog odbora.

H3: Neučinkovitost eksterne revizije povezana je s otvaranjem stečajeva nad dijelom kreditnih institucija.

\section{TEORIJSKI OKVIR}

\subsection{Važnost upravljačkih struktura i eksterne revizije u kreditnim institucijama}

Kreditne institucije su institucije kojima je Hrvatska narodna banka izdala odobrenje za rad u skladu sa Zakonom o kreditnim institucijama, a čija je djelatnost primanje depozita ili ostalih povratnih sredstava od javnosti te odobravanje kredita za vlastiti račun. Kreditna institucija u Republici Hrvatskoj može se osnovati kao banka, štedna banka ili stambena štedionica. Kreditna institucija ustrojena je kao dioničko društvo. Pod upravljačkim strukturama dioničkog društva u pravilu se razumijevaju njezini organi - uprava, nadzorni odbor i glavna skupština. Ono što ih međusobno razlikuje odnosi se na činjenicu što neki od tih organa imaju vlasničku, a neki menadžersku ulogu te s tim u vezi mogu imati veću odnosno manju moć u društvu. Uprava, nadzorni odbor i glavna skupština tri su obvezna organa koje dioničko društvo, kao jedini oblik trgovačkog društva, mora imati (Mlikotin-Tomić i sur., 1994:212). „U dioničkom društvu ovlasti imaju organi, a ne članovi društva. Članovi društva (dioničari) mogu, ali ne moraju, biti članovi organa društva, a glavna skupština jedini je organ u kojemu oni ostvaruju svoja upravljačka prava“ (Barbić, 2007:425). Korporativno upravljanje u kreditnim institucijama u određenoj se mjeri razlikuje od korporativnog upravljanja u ostalim dioničkim društvima (Jurić, 2013: 361).

Nadzorni odbor svojstven je kontinentalnom modelu korporativnog upravljanja i predstavlja interni mehanizam korporativnog upravljanja (Tušek, Filipović, Pokrovac, 2008:224). „Funkcija vođenja i upravljanja delegirana je upravi, dok nadzorni odbor preuzima funkciju kontrole, nadgledanja i praćenja poslovanja društva“" (Tipurić, 2006:119). Radi efikasnijeg rada nadzorni odbor ima mogućnost 
imenovati komisije odnosno odbore. Tri su komisije/odbora koje nadzorni odbor u pravilu osniva. To su: a) revizijski odbor, b) odbor za imenovanja i c) odbor za nagrađivanje.

Odnos organa dioničkog društva nije hijerarhijski. Taj odnos počiva na njihovoj ravnoteži. Svaki od tih organa crpi svoje ovlasti iz Zakona o trgovačkim društvima. Slijedom toga, „glavna skupština nije nadređena upravi i nadzornom odnosno upravnom odboru u obavljanju njihovih zadaća“ i ona „,ne može odlučivati o stvarima koje su u djelokrugu drugih organa društva“" (Gorenc i sur., 2008:584$585)$.

U svome radu upravljačke se strukture oslanjaju na različite mehanizme korporativnog upravljanja. Među njima važno mjesto pripada eksternoj reviziji. Eksterna revizija je „sinonim za reviziju financijskih izvještaja“ (Filipović, Bartulović, Filipović, 2018:101). Pod eksternom revizijom najčešće se razumijeva postupak neovisnog ispitivanja i ocjenjivanja realnosti i objektivnosti informacija sadržanih u financijskim izvještajima. Pri tome se realnost i objektivnost financijskih izvještaja ocjenjuje na temelju njihove usklađenosti sa zakonskim propisima, računovodstvenim načelima i standardima te računovodstvenim politikama (Tušek, Filipović, Filipović, 2009:122). Propisi, Međunarodni standardi kontrole kvalitete, revidiranja, uvida, ostalih izražavanja uvjerenja i povezanih usluga (u daljnjem tekstu: Međunarodni standardi) i Kodeks etike za profesionalne računovođe okvir su djelovanja eksterne revizije. Proces eksterne revizije tvore sljedeće faze: a) procjena rizika značajnog pogrešnog prikazivanja financijskih izvještaja, b) reakcija na rizike značajnog pogrešnog prikazivanja financijskih izvještaja te c) dovršavanje i izvješćivanje o financijskim izvještajima (Filipović, Bartulović, Filipović, 2018:147).

Kruna svakoga angažmana eksternog revizora je njegovo izvješće. Revizorsko izvješće sadržava, uz ostale propisane dijelove, i dio koji se odnosi na mišljenje revizora. Nakon obavljene revizije od eksternog revizora očekuje se da upravi kreditne institucije i Hrvatskoj narodnoj banci dostavi pismo preporuka upravi. Pri obavljanju revizije financijskih izvještaja eksterni revizori primjenjuju Međunarodne revizijske standarde. Neki se od tih standarda izravno odnosno neizravno bave komuniciranjem eksternih revizora s upravljačkim strukturama bilo kojeg poslovnog subjekta, pa tako i kreditne institucije. Kako bi na profesionalan način obavili reviziju godišnjih financijskih izvještaja eksterni revizori moraju biti neovisni o kreditnoj instituciji čije financijske izvještaje revidiraju. Ta neovisnost ključna je pretpostavka za formiranje mišljenja eksternog revizora o istinitosti i objektivnosti tih financijskih izvještaja.

Obavljajući reviziju eksterni revizori ostvaruju suradnju s upravom, nadzornim i revizijskim odborom te glavnom skupštinom kreditne institucije. Pristup 
svakoj karici u navedenom lancu treba biti „,potpun i neometan“.1 Osnovu za komunikaciju eksternog revizora s upravljačkim strukturama kreditne institucije čine: ${ }^{2}$ a) Međunarodni revizijski standard (MRevS) 210 - Dogovaranje uvjeta revizijskih angažmana, b) MRevS 260 (izmijenjen) - Komuniciranje s onima koji su zaduženi za upravljanje i c) MRevS 265 - Priopćavanje nedostataka u internim kontrolama onima koji su zaduženi za upravljanje i menadžmentu.

S obzirom na to da su kreditne institucije od velike važnosti za gospodarstvo svake zemlje, njihovo poslovanje stalno prate supervizori - najčešće središnje monetarne institucije. Tako su banke, štedne banke i stambene štedionice u Republici Hrvatskoj izložene kontinuiranom nadzoru, osim internih i eksternih revizora, i supervizora - Hrvatske narodne banke. Opravdanost potrebe za pojačanim nadzorom kreditnih institucija posljedica je, zbog - među ostalim - činjenice da posluju s velikim iznosima posuđenih sredstava, njihove povećane ranjivosti na negativna gospodarska kretanja i njihova povećana rizika kolapsa. ${ }^{3}$

\subsection{Prethodna istraživanja odnosa eksterne revizije i upravljačkih struktura poslovnih subjekata}

Literatura poznaje istraživanja koja su se bavila odnosima eksterne revizije i upravljačkih struktura. Tim istraživanjima navedeni odnosi analizirani su iz različitih perspektiva i samo manjim dijelom odnosili su se na kreditne institucije, što je intencija ovoga rada. Tako, Colbert (2002), analizirajući obveze internih i eksternih revizora u kontekstu komuniciranja s onima koji su zaduženi za upravljanje sukladno mjerodavnim standardima koji predstavljaju okvir za njihovo profesionalno djelovanje, promatra upravljačke strukture poduzeća kao stjecište informacija s dviju adresa, internih i eksternih revizora. $\mathrm{S}$ tim u vezi bavi se dilemom jesu li informacije dobivene od jedne strane (internih revizora) dopuna dostavljenog izvješća druge strane (eksternih revizora), te je li paralelno izvještavanje internih

1 Međunarodni revizijski standardi, Međunarodni standardi kontrole kvalitete, Međunarodne smjernice revizijske prakse (2010) - prijevod s engleskog jezika, Hrvatska revizorska komora, Zagreb. Međunarodna smjernica revizijske prakse 1004 - Odnos između supervizora banaka i vanjskih revizora banaka, toč. 9 ., op. cit., 806 .

2 Hrvatska revizorska komora, Međunarodni revizijski standardi. Raspoloživo na: http:// www.revizorska-komora.hr/index.php/kodeks-standardi-smjernice/medjunarodni-revizijski-standardi.html [pristupljeno: 20. siječnja 2019.].

3 Međunarodni revizijski standardi, Međunarodni standardi kontrole kvalitete, Međunarodne smjernice revizijske prakse (2010) - prijevod s engleskog jezika, Hrvatska revizorska komora, Zagreb. Međunarodna smjernica revizijske prakse 1004 - Odnos između supervizora banaka i vanjskih revizora banaka, toč. 18., op. cit., 809 . 
i eksternih revizora nepotrebno dupliciranje informacija i revizijskog angažmana. Navedeni autor zaključuje kako angažman internih i eksternih revizora ima dosta sličnosti te da zajedno ti revizori predstavljaju snažnu podršku upravljačkim strukturama u ostvarenju poslovnih ciljeva poduzeća. Uz to se naglašava kako su eksterni revizori u svom radu više orijentirani zadovoljiti sve zainteresirane korisnike informacija iz financijskih izvještaja, dok su interni revizori ponajprije orijentirani na upravljačke strukture poslovnih subjekata.

Haron i sur. (2004) nastoje, u istraživanju koje su proveli, utvrditi ključne kriterije koje eksterni revizori uzimaju u obzir pri donošenju odluke hoće li se pri obavljanju revizije financijskih izvještaja osloniti na rezultate rada internog revizora. Provedenim istraživanjem došli su do zaključka kako su kompetencije internih revizora i njihov djelokrug rada odlučujući čimbenici koji utječu na eksterne revizore hoće li se osloniti na rezultate rada internih revizora. Osim toga, to istraživanje nastoji dati odgovor na pitanje hoće li se eksterni revizor prije osloniti na rezultate rada interne revizije koja je ustrojena u poslovnom subjektu ili su te usluge eksternalizirane. U takvu nastojanju zaključuju kako će se eksterni revizori prije osloniti na eksternalizirane usluge interne revizije, jer tu internu reviziju karakterizira veći stupanj neovisnosti od one ustrojene u bilo kojem poslovnom subjektu. Smatraju kako je interna revizija ustrojena unutar poduzeća pod većim utjecajem upravljačkih struktura. Uz to, sublimirajući prethodna istraživanja, navode kako eksternom revizoru pri odluci da se koristi rezultatima rada interne revizije pomažu sljedeća četiri ključna čimbenika: 1) status interne revizije u organizaciji (je li neovisna ili ne), 2) djelokrug rada interne revizije, 3) tehničke kompetencije (potrebna znanja i vještine internih revizora) i 4) profesionalna pažnja internih revizora (je li revizija pravilno planirana, provedena i dokumentirana).

Cohen i sur. (2007) u okviru svog istraživanja obrađuju komunikaciju revizora s revizijskim odborom i onima koji su zaduženi za upravljanje. U tom istraživanju naglasak stavljaju na to kako komunikacija revizora s upravljačkim strukturama može imati utjecaj na financijske izvještaje, interne kontrole i kvalitetu rada eksternog revizora. Podsjećajući na prethodna istraživanja autori ističu kako je komunikacija eksternog revizora s revizijskim odborom nedostatna, nekvalitetna i limitirana, te da je njihov dijalog potrebno unaprijediti posebice zbog važne uloge revizijskog odbora u području financijskog izvještavanja. Temeljem provedenoga istraživanja sugerira se: a) da komunikacija bude učestalija nego što je bio slučaj, iz razloga što se na taj način mogu reducirati prijevare i prijevarno izvještavanje, b) da revizor i revizijski odbor više raspravljaju o područjima/pitanjima u kojima menadžment vidi svoju priliku za dodatne zarade kroz počinjenje prijevare i c) da revizor i revizijski odbor više raspravljaju o pozicijama koje nisu uključene u financijske izvještaje. Uza sve navedeno istaknuto je kako revizijski odbor komu- 
nicirajući s eksternim revizorom može dati adekvatnu podršku internim revizorima o pojedinim pitanjima i kako ta komunikacija može pridonijeti kvaliteti rada odjela interne revizije.

Gras-Gil, Marin-Hernandez i Garcia-Perez de Lema (2012) u svom istraživanju analiziraju vezu između rada internih revizora i kvalitete financijskih izvještaja u španjolskom bankovnom sektoru. Rezultati provedenog istraživanja pokazali su da u bankama koje imaju na najbolji mogući način sastavljene i prikazane financijske izvještaje postoji visok stupanj komunikacije internih i eksternih revizora te da veća uključenost interne revizije u nadzor financijskih izvještaja pridonosi njihovoj većoj vjerodostojnosti.

Revizijski odbor i njegova uloga u korporativnom upravljanju u fokusu su istraživanja koje su proveli Ghafran i O'Sullivan (2013). Brojna su prethodna istraživanja pokazala, kako ističu ovi autori, da investitori na organiziranim tržištima kapitala očekuju da poduzeća imaju revizijski odbor te da su spremniji ulagati kad su u te odbore imenovani relevantni stručnjaci. Zajedničko svim prethodnim istraživanjima je i to, kako naglašavaju navedeni autori, da neovisnost, stručnost i učestalost sastajanja revizijskog odbora vodi njegovoj većoj učinkovitosti. Rezultati do kojih su došli autori ovoga istraživanja upućuju na to da veći revizijski odbori, koji imaju visok stupanj neovisnosti i čiji su članovi eksperti u području financija i računovodstva, traže kvalitetnije eksterne revizore koji će im pružiti „sigurniju“ razinu uvjerenja o financijskim izvještajima. Nadalje, autori zaključuju kako neovisni revizijski odbori neće koristiti druge ne-revizijske usluge od istog eksternog revizora. Uz to, konsenzus postoji i oko toga da neovisni revizijski odbori - čiji članovi imaju veliko financijsko-računovodstveno znanje - pridonose kvaliteti financijskih izvještaja.

Istraživanje o odnosima revizijskog odbora kao mehanizma korporativnog upravljanja i dioničara te izvršnih direktora proveli su i Husnin, Nawawi i Salin (2016). Tim je istraživanjem analiziran i odabir revizora prije i poslije uvođenja Kodeksa korporativnog upravljanja u Maleziji 2007. Tim je Kodeksom utvrđeno da se revizijski odbor mora sastojati od članova koji nisu izvršni direktori poduzeća, kao i to da se sastanci revizijskog odbora s revizorima održavaju bez nazočnosti članova uprave odnosno izvršnih direktora. Rezultati istraživanja pokazali su kako je Kodeks korporativnog upravljanja utjecao na kvalitetniju selekciju revizora nakon njegova donošenja.

Iz prethodno navedenoga prikaza dosadašnjih istraživanja može se zaključiti kako nema puno istraživanja koja su se bavila odnosima eksterne revizije i upravljačkih struktura u kreditnim institucijama. Upravo zbog toga ovaj rad, nastavljajući dosadašnja istraživanja, u prvi plan stavlja odnose eksterne revizije i upravljačkih struktura u kreditnim institucijama. 
M. FILIPOVIĆ: Istraživanje odnosa upravljačkih struktura i eksterne revizije u korporativnom upravljanju EKONOMSKI PREGLED, 72 (4) 522-549 (2021)

\subsection{Model komuniciranja eksternih revizora i upravljačkih struktura kreditne institucije}

Nadzor eksternih revizora sam po sebi ne bi imao nikakvog smisla kada se rezultati toga rada ne bi priopćavali ponajprije onima koji su zaduženi za upravljanje. Preduvjet za svrhovit rad eksterne revizije je uspostavljena komunikacija tog nadzornog mehanizma s upravljačkim strukturama kreditne institucije. Izostanak takve komunikacije u pravilu za posljedicu ima neučinkovito obavljanje toga oblika nadzora, ali i neučinkovit rad upravljačkih struktura kreditnih institucija. Stoga su i eksterni revizori i upravljačke strukture zainteresirani za oblikovanje komunikacijskog modela koji bi pospješio rad eksternih revizora i onih koji su zaduženi za upravljanje kreditnom institucijom.

Slika 1 .

\section{KOMUNIKACIJSKI MODEL EKSTERNE REVIZIJE I UPRAVLJAČKIH STRUKTURA KREDITNE INSTITUCIJE}

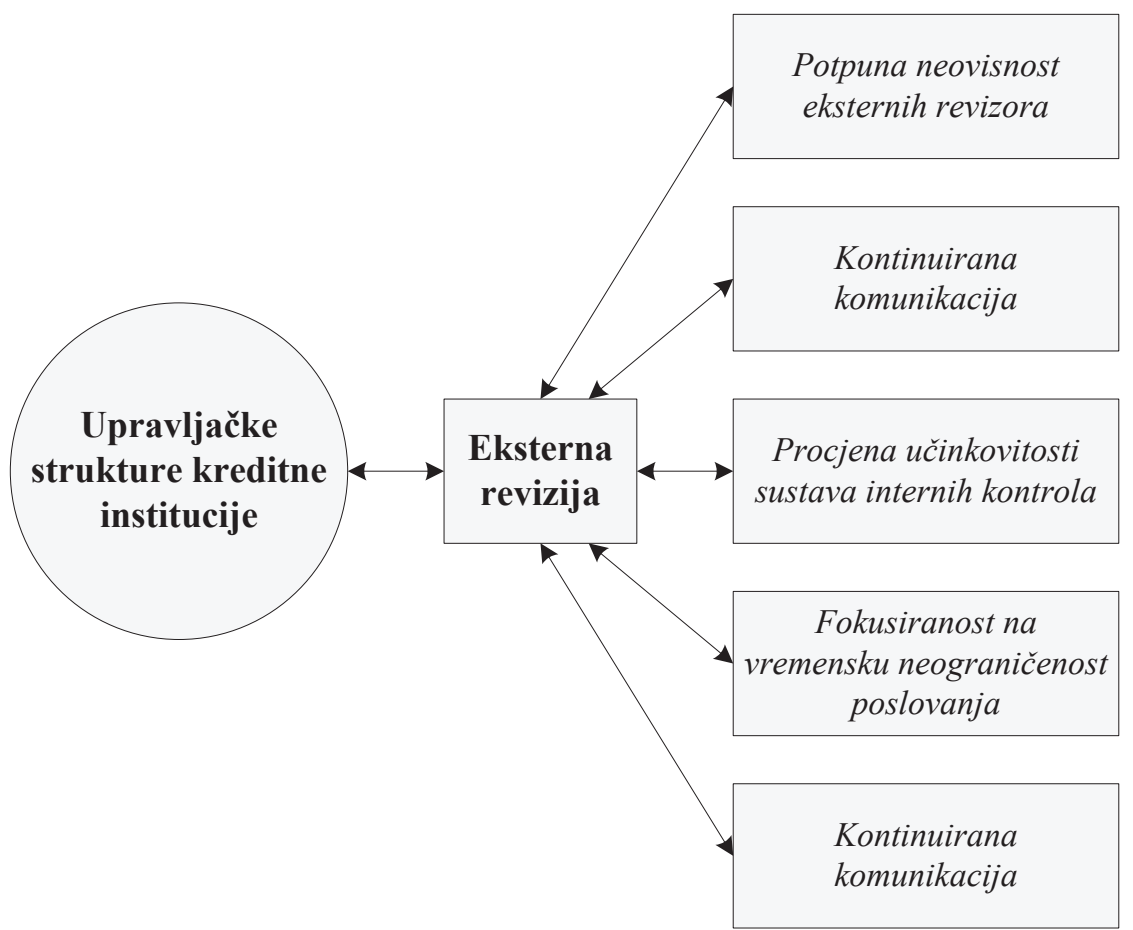

Izvor: Autor rada 
Predloženi komunikacijski model (slika 1.) bavi se odnosima eksternih revizora i upravljačkih struktura kreditne institucije i čine ga sljedeće komponente:

I. potpuna neovisnost rada eksternih revizora u kreditnoj instituciji

II. kontinuirana komunikacija ${ }^{4}$ eksternih revizora s članovima uprave, nadzornog i revizijskog odbora kreditne institucije

III. procjena, od strane eksternih revizora, učinkovitosti i prikladnosti sustava internih kontrola nad financijskim izvještavanjem kreditne institucije

IV. fokusiranost eksternih revizora na pretpostavku vremenski neograničenog poslovanja kreditne institucije i

V. usredotočenost eksterne revizije na ona područja rada kreditne institucije koja su izvor potencijalnih prijevara.

Za pretpostaviti je kako prikazani model odnosa eksternih revizora i upravljačkih struktura kreditne institucije može pridonijeti boljem radu eksterne revizije, s jedne strane, te upravljačkih struktura, s druge strane.

\section{METODOLOGIJA ISTRAŽIVANJA}

Za potrebe provjere hipoteza korištena su tri različita anketna upitnika namijenjena eksternim revizorima koji obavljaju ili su obavljali reviziju godišnjih financijskih izvještaja kreditnih institucija, članovima uprave i nadzornih odbora kreditnih institucija kao i stečajnim upraviteljima i stručnom osoblju kreditnih institucija u stečaju u Republici Hrvatskoj. Upitnike je ukupno ispunilo 127 ispitanika, a tablica 1. prikazuje uzorak ispitanika.

4 Pod kontinuiranom komunikacijom razumijevaju se mjesečni, po potrebi tjedni sastanci eksternih revizora s članovima uprave, nadzornog i revizijskog odbora kreditne institucije. 
Tablica 1 .

\section{UZORAK ISPITANIKA}

\begin{tabular}{|l|c|c|}
\hline Naziv upitnika & Uzorak & Broj ispitanika \\
\hline Upitnik 1 & $\begin{array}{c}\text { Eksterni revizori koji obavljaju ili su obavljali } \\
\text { reviziju godišnjih financijskih izvještaja kreditnih } \\
\text { institucija }\end{array}$ & 52 \\
\hline Upitnik 2 & $\begin{array}{c}\text { Članovi uprave i nadzornih odbora kreditnih } \\
\text { institucija }\end{array}$ & 48 \\
\hline Upitnik 3 & $\begin{array}{c}\text { Stečajni upravitelji i stručno osoblje kreditnih } \\
\text { institucija u stečaju }\end{array}$ & 27 \\
\hline & UKUPNO & $\mathbf{1 2 7}$ \\
\hline
\end{tabular}

Izvor: Istraživanje autora rada

U nastavku slijede metodološka pojašnjenja hipoteza. Kada je riječ o hipotezi H1, pod kvalitetom komuniciranja eksternih revizora s upravljačkim strukturama kreditne institucije razumijeva se učestalost i sadržajnost njihovih sastanaka. Kvaliteta komuniciranja mjerena je dobivenim odgovorima ispitanika na pitanja postavljena u anketnom upitniku, kao što su: „1. komunikacije nema, 2. komunikacija je slaba, 3. komunikacija je osrednja, 4. komunikacija je vrlo dobra, 5. komunikacija je izvrsna.“ Pod (ne)učinkovitošću eksterne revizije razumijeva se (ne) ispunjavanje njezinih zadaća u skladu s Međunarodnim revizijskim standardima. Pod (ne)učinkovitošću upravljačkih struktura kreditne institucije (uprava, nadzorni odbor, glavna skupština) razumijeva se (ne)ispunjavanje njihovih zadaća u skladu s propisima i planovima poslovanja. Utjecaj kvalitete komuniciranja eksternih revizora s upravljačkim strukturama kreditne institucije na njihovu učinkovitost mjerena je također dobivenim odgovorima ispitanika na pitanja postavljena u anketnom upitniku. Ta su pitanja usmjerena na predloženi model odnosa eksternih revizora i upravljačkih struktura kreditne institucije. Ispitanici su na ta pitanja mogli odgovoriti kako predloženi model tih odnosa: „1. ne pridonosi, 2. neznatno pridonosi, 3. osrednje pridonosi, 4. jako pridonosi, 5. izrazito jako pridonosi“" boljem radu eksterne revizije i upravljačkih struktura kreditne institucije.

Kad je riječ o hipotezi H2 pod kvalitetom komuniciranja eksternih revizora s revizijskim odborom kreditne institucije razumijeva se učestalost i sadržajnost njihovih sastanaka. Kvaliteta komuniciranja mjerena je dobivenim odgovorima ispitanika na pitanja postavljena u anketnom upitniku, kao što su: „1. komunikacije nema, 2. komunikacija je slaba, 3. komunikacija je osrednja, 4. komunikacija je vrlo dobra, 5. komunikacija je izvrsna.“ 
Hipoteza H3 razvijena je kako bi se testirala povezanost neučinkovitosti eksterne revizije s otvaranjem stečajeva nad dijelom kreditnih institucija u Republici Hrvatskoj. Ta povezanost utvrđena je odgovorima ispitanika na pitanje postavljeno u anketnom upitniku ,je li neučinkovitost eksterne revizije povezana s otvaranjem stečaja nad kreditnom institucijom“, kao što su: „1. nije povezana, 2. neznatno je povezana, 3. osrednje je povezana, 4. jako je povezana, 5. izrazito jako je povezana.“ Posebnoj skupini ispitanika (onima koji su kao stečajni upravitelji ili stručne osobe angažirani u kreditnim institucijama u stečaju) postavljeno je pitanje ,,je li neučinkovitost eksterne revizije pridonijela otvaranju stečaja nad kreditnom institucijom u kojoj su angažirani“". Na to su pitanje ispitanici mogli odgovoriti s: „1. nije pridonijela, 2. neznatno je pridonijela, 3. osrednje je pridonijela, 4. jako je pridonijela, 5. izrazito jako je pridonijela." Posebnoj skupini ispitanika (eksternim revizorima) postavljeno je pitanje ,slažu li se s konstatacijom da su eksterni revizori na vrijeme upozorili na upitnost vremenski neograničenog poslovanja, tada nad dijelom kreditnih institucija ne bi bio pokrenut stečaj." Na to pitanje mogli su odgovoriti s: „1. u potpunosti se ne slažem, 2. ne slažem se, 3. niti se slažem niti se ne slažem, 4. slažem se, 5. u potpunosti se slažem.“

Za potrebe empirijskog istraživanja u okviru ovoga rada provedeno je kvantitativno istraživanje. Proces analize sastojao se iz nekoliko faza. Najprije je procijenjena pouzdanost primijenjenih mjernih ljestvica putem Cronbach alfa koeficijenata. Prilikom daljnje analize primijenjena je deskriptivna statistika, model jednostavne linearne regresije te korelacijska analiza.

\section{REZULTATI EMPIRIJSKOG ISTRAŽIVANJA}

U ovom poglavlju prikazani su rezultati deskriptivne statistike, regresijske i korelacijske analize. U sklopu deskriptivne statistike primijenjene su mjere centralne tendencije ili mjere prosjeka kao što su aritmetička sredina i medijan, zatim mjere disperzije kao što su standardna devijacija i varijanca te mjere oblika distribucije - koeficijent asimetrije i mjera zaobljenosti. 
M. FILIPOVIĆ: Istraživanje odnosa upravljačkih struktura i eksterne revizije u korporativnom upravljanju EKONOMSKI PREGLED, 72 (4) 522-549 (2021)

Tablica 2.

\section{DESKRIPTIVNA ANALIZA KVALITETE KOMUNIKACIJE IZ PERSPEKTIVE EKSTERNIH REVIZORA KOJI OBAVLJAJU ILI SU OBAVLJALI REVIZIJU GODIŠNJIH FINANCIJSKIH IZVJEŠTAJA KREDITNIH INSTITUCIJA}

\begin{tabular}{|l|c|c|c|c|c|c|}
\hline & $\begin{array}{c}\text { Aritmetička } \\
\text { sredina }\end{array}$ & Medijan & $\begin{array}{c}\text { Standardna } \\
\text { devijacija }\end{array}$ & Varijanca & $\begin{array}{c}\text { Koeficijent } \\
\text { asimetrije }\end{array}$ & $\begin{array}{c}\text { Mjera } \\
\text { zaobljenosti }\end{array}$ \\
\hline $\begin{array}{l}\text { Kvaliteta } \\
\text { komunikacije } \\
\text { eksternih revizora } \\
\text { i upravljačkih } \\
\text { struktura (uprave i } \\
\text { nadzornog odbora) } \\
\text { kreditne institucije }\end{array}$ & 4,12 & 4 & 0,58 & 0,34 & $-0,01$ & 0,00 \\
\hline $\begin{array}{l}\text { Kvaliteta } \\
\text { komunikacije } \\
\text { eksternih revizora i } \\
\text { revizijskog odbora } \\
\text { kreditne institucije }\end{array}$ & 3,88 & 4 & 0,86 & 0,73 & $-0,55$ & $-0,09$ \\
\hline
\end{tabular}

Izvor: Istraživanje autora rada

Eksterni su revizori veću prosječnu ocjenu dodijelili (tablica 2.) kvaliteti komunikacije s upravljačkim strukturama kreditnih institucija $(4,12)$ nego kvaliteti komunikacije s revizijskim odborom $(3,88)$. 
Tablica 3 .

\section{DESKRIPTIVNA ANALIZA VARIJABLI VEZANIH UZ NEUČINKOVITOST EKSTERNE REVIZIJE I UTJECAJ UPOZORENJA NA UPITNOST VREMENSKI NEOGRANIČENOG POSLOVANJA, IZ PERSPEKTIVE EKSTERNIH REVIZORA KOJI OBAVLJAJU ILI SU OBAVLJALI REVIZIJU GODIŠNJIH FINANCIJSKIH IZVJEŠTAJA KREDITNIH INSTITUCIJA}

\begin{tabular}{|l|c|c|c|c|c|c|}
\hline & $\begin{array}{c}\text { Aritmetička } \\
\text { sredina }\end{array}$ & Medijan & $\begin{array}{c}\text { Standardna } \\
\text { devijacija }\end{array}$ & Varijanca & $\begin{array}{c}\text { Koeficijent } \\
\text { asimetrije }\end{array}$ & $\begin{array}{c}\text { Mjera } \\
\text { zaobljenosti }\end{array}$ \\
\hline $\begin{array}{l}\text { Povezanost } \\
\text { neučinkovitosti } \\
\text { eksterne revizije } \\
\text { s razvojem } \\
\text { nepoželjnog } \\
\text { poslovnog scenarija } \\
\text { koji uključuje i } \\
\text { otvaranje stečaja } \\
\text { nad kreditnom } \\
\text { institucijom }\end{array}$ & 3,52 & 4 & 1,21 & 1,47 & $-0,70$ & $-0,30$ \\
\hline $\begin{array}{l}\text { Utjecaj upozorenja } \\
\text { eksternih revizora } \\
\text { vezano uz upitnost } \\
\text { vremenski } \\
\text { neograničenog } \\
\text { poslovanja na } \\
\text { pokretanje stečaja }\end{array}$ & 3,94 & 4 & 1,16 & 1,35 & $-0,98$ & 0,04 \\
\hline
\end{tabular}

Izvor: Istraživanje autora rada

Ispitanici su veću prosječnu ocjenu dodijelili (tablica 3.) utjecaju upozorenja eksternih revizora vezano uz upitnost vremenski neograničenog poslovanja na pokretanje stečaja $(3,94)$ nego varijabli povezanost neučinkovitosti eksterne revizije s razvojem nepoželjnog poslovnog scenarija koji uključuje i otvaranje stečaja nad kreditnom institucijom $(3,52)$. 
M. FILIPOVIĆ: Istraživanje odnosa upravljačkih struktura i eksterne revizije u korporativnom upravljanju EKONOMSKI PREGLED, 72 (4) 522-549 (2021)

\section{Tablica 4.}

\section{DOPRINOS MODELA ODNOSA EKSTERNIH REVIZORA I UPRAVLJAČKIH STRUKTURA KREDITNE INSTITUCIJE BOLJEM RADU EKSTERNE REVIZIJE I UPRAVLJAČKIH STRUKTURA KREDITNE INSTITUCIJE, IZ PERSPEKTIVE EKSTERNIH REVIZORA KOJI OBAVLJAJU ILI SU OBAVLJALI REVIZIJU GODIŠNJIH FINANCIJSKIH IZVJEŠTAJA KREDITNIH INSTITUCIJA}

\begin{tabular}{|l|c|c|c|c|c|c|}
\hline & $\begin{array}{c}\text { Aritmetička } \\
\text { sredina }\end{array}$ & Medijan & $\begin{array}{c}\text { Standardna } \\
\text { devijacija }\end{array}$ & Varijanca & $\begin{array}{c}\text { Koeficijent } \\
\text { asimetrije }\end{array}$ & $\begin{array}{c}\text { Mjera } \\
\text { zaobljenosti }\end{array}$ \\
\hline $\begin{array}{l}\text { Potpuna neovisnost rada } \\
\text { eksternih revizora u kreditnoj } \\
\text { instituciji }\end{array}$ & 4,50 & 5 & 0,61 & 0,37 & $-0,80$ & $-0,28$ \\
\hline $\begin{array}{l}\text { Kontinuirana (mjesečna, po } \\
\text { potrebi i tjedna) komunikacija } \\
\text { eksternih revizora s članovima } \\
\text { uprave, nadzornog i revizijskog } \\
\text { odbora kreditne institucije }\end{array}$ & 4,13 & 4 & 0,79 & 0,63 & $-1,47$ & 4,23 \\
\hline $\begin{array}{l}\text { Procjena, od strane eksternih } \\
\text { revizora, učinkovitosti i pri- } \\
\text { kladnosti sustava internih kon- } \\
\text { trola nad financijskim izvješta- } \\
\text { vanjem kreditne institucije }\end{array}$ & 4,13 & 4 & 0,93 & 0,86 & $-1,64$ & 3,64 \\
\hline $\begin{array}{l}\text { Fokusiranost eksternih } \\
\text { revizora na pretpostavku } \\
\text { vremenski neograničenog } \\
\text { poslovanja kreditne institucije }\end{array}$ & 4,12 & 4,5 & 1,11 & 1,24 & $-1,20$ & 0,77 \\
\hline $\begin{array}{l}\text { Usredotočenost eksterne } \\
\text { revizije na ona područja rada } \\
\text { kreditne institucije koja su } \\
\text { izvor potencijalnih prijevara }\end{array}$ & 4,25 & 4 & 0,90 & 0,82 & $-1,51$ & 2,74 \\
\hline $\begin{array}{l}\text { UKUPNO - model } \\
\text { odnosa eksternih revizora } \\
\text { i upravljačkih struktura } \\
\text { kreditne institucije }\end{array}$ & 4,23 & 4,30 & 0,87 & 0,78 & $-1,33$ & 2,22 \\
\hline
\end{tabular}

Izvor: Istraživanje autora rada

Prosječna vrijednost komponenti modela iznosi 4,23 što upućuje na zaključak kako model odnosa eksternih revizora upravljačkih struktura kreditne institucije jako pridonosi boljem radu eksterne revizije, s jedne strane, te upravljačkih struktura kreditne institucije, s druge strane. U nastavku slijedi prikaz rezultata deskriptivne analize vezane uz članove uprave i nadzornih odbora kreditnih institucija. 
Tablica 5 .

\section{DESKRIPTIVNA ANALIZA KVALITETE KOMUNIKACIJE S EKSTERNIM REVIZORIMA, IZ PERSPEKTIVE ČLANOVA UPRAVE I NADZORNIH ODBORA KREDITNIH INSTITUCIJA}

\begin{tabular}{|l|c|c|c|c|c|c|}
\hline & $\begin{array}{c}\text { Aritmetička } \\
\text { sredina }\end{array}$ & Medijan & $\begin{array}{c}\text { Standardna } \\
\text { devijacija }\end{array}$ & Varijanca & $\begin{array}{c}\text { Koeficijent } \\
\text { asimetrije }\end{array}$ & $\begin{array}{c}\text { Mjera } \\
\text { zaobljenosti }\end{array}$ \\
\hline $\begin{array}{l}\text { Kvaliteta komunikacije } \\
\text { upravljačkih struktura (uprave } \\
\text { i nadzornog odbora) kreditne } \\
\text { institucije i eksternih revizora }\end{array}$ & 4,10 & 4 & 0,72 & 0,52 & 0,71 & 1,66 \\
\hline $\begin{array}{l}\text { Kvaliteta komunikacije } \\
\text { revizijskog odbora kreditne } \\
\text { institucije i eksternih revizora }\end{array}$ & 4,21 & 4 & 0,65 & 0,42 & $-1,57$ & 6,29 \\
\hline
\end{tabular}

Izvor: Istraživanje autora rada

Članovi uprave i nadzornih odbora kreditnih institucija veću su prosječnu ocjenu dodijelili kvaliteti komunikacije revizijskog odbora kreditne institucije i eksternih revizora $(4,21)$, dok su nižu prosječnu ocjenu $(4,10)$ dodijelili kvaliteti komunikacije upravljačkih struktura (uprave i nadzornog odbora) kreditne institucije i eksternih revizora.

\section{Tablica 6.}

DESKRIPTIVNA ANALIZA VARIJABLI VEZANIH UZ POVEZANOST NEUČINKOVITOSTI EKSTERNE REVIZIJE I NEPOŽELJNOG POSLOVNOG SCENARIJA KOJI UKLJUČUJE I OTVARANJE STEČAJA NAD KREDITNOM INSTITUCIJOM, IZ PERSPEKTIVE ČLANOVA UPRAVE I NADZORNIH ODBORA KREDITNIH INSTITUCIJA

\begin{tabular}{|l|c|c|c|c|c|c|}
\hline & $\begin{array}{c}\text { Aritmetička } \\
\text { sredina }\end{array}$ & Medijan & $\begin{array}{c}\text { Standardna } \\
\text { devijacija }\end{array}$ & Varijanca & $\begin{array}{c}\text { Koeficijent } \\
\text { asimetrije }\end{array}$ & $\begin{array}{c}\text { Mjera } \\
\text { zaobljenosti }\end{array}$ \\
\hline $\begin{array}{l}\text { Povezanost neučinkovitosti } \\
\text { eksterne revizije s razvojem } \\
\text { nepoželjnog poslovnog } \\
\text { scenarija koji uključuje } \\
\text { i otvaranje stečaja nad } \\
\text { kreditnom institucijom }\end{array}$ & 4,19 & 4 & 0,82 & 0,67 & $-1,34$ & 3,49 \\
\hline
\end{tabular}

Izvor: Istraživanje autora rada 
Članovi uprave i nadzornih odbora kreditnih institucija smatraju kako je neučinkovitost eksterne revizije jako povezana s razvojem nepoželjnog poslovnog scenarija koji uključuje i otvaranje stečaja nad kreditnom institucijom čemu u prilog ide visoka prosječna ocjena 4,19.

\section{Tablica 7.}

\section{DOPRINOS MODELA ODNOSA EKSTERNIH REVIZORA I UPRAVLJAČKIH STRUKTURA KREDITNE INSTITUCIJE BOLJEM RADU EKSTERNE REVIZIJE I UPRAVLJAČKIH STRUKTURA KREDITNE INSTITUCIJE, IZ PERSPEKTIVE ČLANOVA UPRAVE I NADZORNIH ODBORA KREDITNIH INSTITUCIJA}

\begin{tabular}{|l|c|c|c|c|c|c|}
\hline & $\begin{array}{c}\text { Aritmetička } \\
\text { sredina }\end{array}$ & Medijan & $\begin{array}{c}\text { Standardna } \\
\text { devijacija }\end{array}$ & Varijanca & $\begin{array}{c}\text { Koeficijent } \\
\text { asimetrije }\end{array}$ & $\begin{array}{c}\text { Mjera } \\
\text { zaobljenosti }\end{array}$ \\
\hline $\begin{array}{l}\text { Potpuna neovisnost rada } \\
\text { eksternih revizora u kreditnoj } \\
\text { instituciji }\end{array}$ & 4,48 & 5 & 0,58 & 0,34 & $-0,02$ & 0,23 \\
\hline $\begin{array}{l}\text { Kontinuirana (mjesečna, po } \\
\text { potrebi i tjedna) komunikacija } \\
\text { eksternih revizora s članovima } \\
\text { uprave, nadzornog i revizijskog } \\
\text { odbora kreditne institucije }\end{array}$ & 4,02 & 4 & 0,56 & 0,32 & $-0,12$ & 0,56 \\
\hline $\begin{array}{l}\text { Procjena, od strane eksternih } \\
\text { revizora, učinkovitosti i } \\
\text { prikladnosti sustava internih } \\
\text { kontrola nad financijskim } \\
\text { izvještavanjem kreditne } \\
\text { institucije }\end{array}$ & 4,33 & 4 & 0,60 & 0,35 & $-0,55$ & 0,15 \\
\hline $\begin{array}{l}\text { Fokusiranost eksternih revizora } \\
\text { na pretpostavku vremenski } \\
\text { neograničenog poslovanja } \\
\text { kreditne institucije }\end{array}$ & 4,44 & 4 & 0,58 & 0,34 & $-0,51$ & 0,35 \\
\hline $\begin{array}{l}\text { Usredotočenost eksterne } \\
\text { revizije na ona područja rada } \\
\text { kreditne institucije koja su izvor } \\
\text { potencijalnih prijevara }\end{array}$ & 4,35 & 4 & 0,60 & 0,36 & $-0,84$ & 2,36 \\
\hline $\begin{array}{l}\text { UKUPNO - model odnosa } \\
\text { eksternih revizora i upravljačkih } \\
\text { struktura kreditne institucije }\end{array}$ & 4,33 & 4 & 0,58 & 0,34 & $-0,40$ & 0,73 \\
\hline
\end{tabular}

Izvor: Istraživanje autora rada 
Prosječna vrijednost komponenti modela odnosa eksternih revizora i upravljačkih struktura iz perspektive članova uprave i nadzornih odbora iznosi 4,33 što upućuje na zaključak kako taj model jako pridonosi boljem radu eksterne revizije, s jedne strane, te upravljačkih struktura kreditne institucije, s druge strane. U nastavku slijedi prikaz rezultata deskriptivne analize vezane uz stečajne upravitelje i stručno osoblje kreditnih institucija u stečaju.

Tablica 8 .

DESKRIPTIVNA ANALIZA KVALITETE KOMUNIKACIJE S EKSTERNIM REVIZORIMA PRIJE POKRETANJA STEČAJA, IZ PERSPEKTIVE STEČAJNIH UPRAVITELJA I STRUČNOG OSOBLJA KREDITNIH INSTITUCIJA U STEČAJU

\begin{tabular}{|l|c|c|c|c|c|c|}
\hline & $\begin{array}{c}\text { Aritmetička } \\
\text { sredina }\end{array}$ & Medijan & $\begin{array}{c}\text { Standardna } \\
\text { devijacija }\end{array}$ & Varijanca & $\begin{array}{c}\text { Koeficijent } \\
\text { asimetrije }\end{array}$ & $\begin{array}{c}\text { Mjera } \\
\text { zaobljenosti }\end{array}$ \\
\hline $\begin{array}{l}\text { Kvaliteta komunikacije } \\
\text { upravljačkih struktura (uprave } \\
\text { i nadzornog odbora) kreditne } \\
\text { institucije i eksternih revizora } \\
\text { prije pokretanja stečaja }\end{array}$ & 2,63 & 3 & 0,63 & 0,40 & 0,56 & 2,36 \\
\hline $\begin{array}{l}\text { Kvaliteta komunikacije } \\
\text { revizijskog odbora kreditne } \\
\text { institucije i eksternih revizora } \\
\text { prije pokretanja stečaja }\end{array}$ & 2,37 & 2 & 0,63 & 0,40 & 0,69 & $-0,22$ \\
\hline
\end{tabular}

Izvor: Istraživanje autora rada

Prema vrijednostima aritmetičke sredine iz tablice 8., stečajni upravitelji i stručno osoblje kreditnih institucija u stečaju, kvalitetu komunikacije upravljačkih struktura (uprave i nadzornog odbora) kreditne institucije i eksternih revizora prije pokretanja stečaja ocijenili su višom prosječnom ocjenom $(2,63)$ u odnosu na kvalitetu komunikacije revizijskog odbora kreditne institucije i eksternih revizora prije pokretanja stečaja $(2,37)$. 
M. FILIPOVIĆ: Istraživanje odnosa upravljačkih struktura i eksterne revizije u korporativnom upravljanju EKONOMSKI PREGLED, 72 (4) 522-549 (2021)

Tablica 9.

DESKRIPTIVNA ANALIZA VARIJABLI VEZANIH UZ DOPRINOS NEUČINKOVITOSTI EKSTERNE REVIZIJE OTVARANJU STEČAJA NAD KREDITNOM INSTITUCIJOM, IZ PERSPEKTIVE STEČAJNIH UPRAVITELJA I STRUČNOG OSOBLJA KREDITNIH INSTITUCIJA U STEČAJU

\begin{tabular}{|l|c|c|c|c|c|c|}
\hline & $\begin{array}{c}\text { Aritmetička } \\
\text { sredina }\end{array}$ & Medijan & $\begin{array}{c}\text { Standardna } \\
\text { devijacija }\end{array}$ & Varijanca & $\begin{array}{c}\text { Koeficijent } \\
\text { asimetrije }\end{array}$ & $\begin{array}{c}\text { Mjera } \\
\text { zaobljenosti }\end{array}$ \\
\hline $\begin{array}{l}\text { Doprinos neučinkovitosti } \\
\text { eksterne revizije otvaranju } \\
\text { stečaja nad kreditnom } \\
\text { institucijom }\end{array}$ & 3,70 & 4 & 0,87 & 0,75 & 0,47 & 2,44 \\
\hline
\end{tabular}

Izvor: Istraživanje autora rada

Stečajni upravitelji i stručno osoblje kreditnih institucija u stečaju smatraju kako je neučinkovitost eksterne revizije jako pridonijela otvaranju stečaja nad kreditnom institucijom (3,70 - aritmetička sredina). 
Tablica 10.

\section{DOPRINOS MODELA ODNOSA EKSTERNIH REVIZORA I UPRAVLJAČKIH STRUKTURA KREDITNE INSTITUCIJE BOLJEM RADU EKSTERNE REVIZIJE I UPRAVLJAČKIH STRUKTURA KREDITNE INSTITUCIJE, IZ PERSPEKTIVE STEČAJNIH UPRAVITELJA I STRUČNOG OSOBLJA KREDITNIH INSTITUCIJA U STEČAJU}

\begin{tabular}{|l|c|c|c|c|c|c|}
\hline & $\begin{array}{c}\text { Aritmetička } \\
\text { sredina }\end{array}$ & Medijan & $\begin{array}{c}\text { Standardna } \\
\text { devijacija }\end{array}$ & Varijanca & $\begin{array}{c}\text { Koeficijent } \\
\text { asimetrije }\end{array}$ & $\begin{array}{c}\text { Mjera } \\
\text { zaobljenosti }\end{array}$ \\
\hline $\begin{array}{l}\text { Potpuna neovisnost rada } \\
\text { eksternih revizora u kreditnoj } \\
\text { instituciji }\end{array}$ & 4,11 & 4 & 0,58 & 0,33 & 0,02 & $-0,05$ \\
\hline $\begin{array}{l}\text { Kontinuirana (mjesečna, po } \\
\text { potrebi i tjedna) komunikacija } \\
\text { eksternih revizora s članovima } \\
\text { uprave, nadzornog i revizijskog } \\
\text { odbora kreditne institucije }\end{array}$ & 3,70 & 4 & 0,67 & 0,45 & 1,23 & $-0,12$ \\
\hline $\begin{array}{l}\text { Procjena, od strane eksternih } \\
\text { revizora, učinkovitosti i } \\
\text { prikladnosti sustava internih } \\
\text { kontrola nad financijskim } \\
\text { izvještavanjem kreditne } \\
\text { institucije }\end{array}$ & 3,78 & 4 & 0,70 & 0,49 & 0,06 & $-1,23$ \\
\hline $\begin{array}{l}\text { Fokusiranost eksternih revizora } \\
\text { na pretpostavku vremenski } \\
\text { neograničenog poslovanja } \\
\text { kreditne institucije }\end{array}$ & 4,33 & 4 & 0,55 & 0,31 & 0,52 & 2,32 \\
\hline $\begin{array}{l}\text { Usredotočenost eksterne } \\
\text { revizije na ona područja rada } \\
\text { kreditne institucije koja su izvor } \\
\text { potencijalnih prijevara }\end{array}$ & 4,26 & 4 & 0,59 & 0,35 & 0,99 & 2,45 \\
\hline $\begin{array}{l}\text { UKUPNO - model odnosa } \\
\text { eksternih revizora i upravljačkih } \\
\text { struktura kreditne institucije }\end{array}$ & 4,04 & 4 & 0,62 & 0,39 & 0,56 & 0,67 \\
\hline
\end{tabular}

Izvor: Istraživanje autora rada

S obzirom na prosječnu vrijednost komponenti modela može se, iz perspektive stečajnih upravitelja i stručnog osoblja kreditnih institucija u stečaju, zaključiti kako model odnosa eksternih revizora i upravljačkih struktura kreditne institucije jako pridonosi boljem radu eksterne revizije, s jedne strane, te upravljačkih struktura kreditne institucije, s druge strane. 
Regresijskom analizom varijabli testirana je prva hipoteza prema kojoj kvaliteta komuniciranja eksternih revizora s upravljačkim strukturama kreditne institucije utječe na učinkovitost eksterne revizije i upravljačkih struktura. Primijenjen je $t$ test na gornju granicu jer je pretpostavljen pozitivan smjer između nezavisne i zavisne varijable. Kao nezavisna varijabla ${ }^{5}$ definirana je kvaliteta komunikacije eksternih revizora s upravljačkim strukturama kreditne institucije, dok je zavisna varijabla učinkovitost eksterne revizije i upravljačkih struktura. Zasebno je provedena regresijska analiza podataka prikupljenih od svih ispitanika. Prije regresijske analize provedena je analiza pouzdanosti mjernih ljestvica kojima se ocjenjivao model odnosa eksternih revizora i upravljačkih struktura kreditne institucije. Cronbach's alpha za spomenuti model iznosi 0,90808761 što predstavlja izrazito visoku pouzdanost modela čime su zadovoljene pretpostavke za primjenu regresijske analize.

\section{Tablica 11 .}

\section{REZULTATI REGRESIJSKE ANALIZE UTJECAJA KVALITETE KOMUNICIRANJA EKSTERNIH REVIZORA S UPRAVLJAČKIM STRUKTURAMA NA UČINKOVITOST EKSTERNIH REVIZORA I UPRAVLJAČKIH STRUKTURA, IZ PERSPEKTIVE EKSTERNIH REVIZORA KOJI OBAVLJAJU ILI SU OBAVLJALI REVIZIJU GODIŠNJIH FINANCIJSKIH IZVJEŠTAJA KREDITNIH INSTITUCIJA}

\begin{tabular}{|l|c|c|c|c|}
\hline & $\begin{array}{c}\text { Procjena } \\
\text { parametara }\end{array}$ & $\begin{array}{c}\text { Standardna } \\
\text { pogreška }\end{array}$ & t vrijednost & p vrijednost \\
\hline Intercept & 2,647890056 & 0,430199766 & 6,155024395 & 0,000000126 \\
\hline$X$ & 0,069435593 & 0,020057748 & 3,461784067 & 0,001108077 \\
\hline
\end{tabular}

Izvor: Istraživanje autora rada

Testiranje se provodi uz razinu signifikantnosti $\alpha=0,05(5 \%)$ i tada je za $n=52$ (broj učitanih opažanja), $\mathrm{t}_{\alpha}(\mathrm{n}-2)=\mathrm{t}_{0,05}(50)=2,01$. Test veličina ( $\mathrm{t}$ vrijednost) $\mathrm{u}$ konkretnom slučaju iznosi $t=\beta$ /standardna pogreška $(\beta)=0,069435593 / 0,020057748$ $=3,461784067$. Budući da je $\mathrm{t}>\mathrm{t}_{\alpha}(\mathrm{n}-2)$ proizlazi zaključak, da se $-\mathrm{uz}$ razinu signifikantnosti $5 \%$ - hipoteza $\mathrm{H} 1$ može prihvatiti. Budući da je p vrijednost u analizi manja od 0,05 hipoteza $\mathrm{H} 1$ može se prihvatiti.

\footnotetext{
${ }_{5}$ Nezavisna varijabla u tablicama regresijske analize je ,,intercept““
} 
Tablica 12.

REZULTATI REGRESIJSKE ANALIZE UTJECAJA KVALITETE

KOMUNICIRANJA EKSTERNIH REVIZORA S UPRAVLJAČKIM

STRUKTURAMA NA UČINKOVITOST EKSTERNIH REVIZORA I

UPRAVLJAČKIH STRUKTURA, IZ PERSPEKTIVE ČLANOVA UPRAVE I NADZORNOG ODBORA KREDITNIH INSTITUCIJA

\begin{tabular}{|l|c|c|c|c|}
\hline & $\begin{array}{c}\text { Procjena } \\
\text { parametara }\end{array}$ & $\begin{array}{c}\text { Standardna } \\
\text { pogreška }\end{array}$ & t vrijednost & p vrijednost \\
\hline Intercept & 1,978120306 & 1,018737866 & 1,941736311 & 0,058308122 \\
\hline $\mathrm{X}$ & 0,081836588 & 0,039022007 & 2,097190632 & 0,041502076 \\
\hline
\end{tabular}

Izvor: Istraživanje autora rada

Testiranje se provodi uz razinu signifikantnosti $\alpha=0,05(5 \%)$ i tada je za $n=48$ (broj učitanih opažanja), $\mathrm{t}_{\alpha}(\mathrm{n}-2)=\mathrm{t}_{0,05}(46)=2,02$. Test veličina ( $\mathrm{t}$ vrijednost) $\mathrm{u}$ konkretnom slučaju iznosi $t=\beta /$ standardna pogreška $(\beta)=0,081836588 / 0,039022007$ $=2,097190632$. Budući da je $\mathrm{t}>\mathrm{t}_{\alpha}(\mathrm{n}-2)$ proizlazi zaključak, da se $-\mathrm{uz}$ razinu signifikantnosti $5 \%$ - hipoteza H1 može prihvatiti. Odluka o ishodu testa može se donijeti i na temelju p vrijednosti. Budući da je p vrijednost u analizi manja od 0,05 hipoteza $\mathrm{H} 1$ može se prihvatiti.

Tablica 13.

REZULTATI REGRESIJSKE ANALIZE UTJECAJA KVALITETE KOMUNICIRANJA EKSTERNIH REVIZORA S UPRAVLJAČKIM STRUKTURAMA NA UČINKOVITOST EKSTERNIH REVIZORA I UPRAVLJAČKIH STRUKTURA, IZ PERSPEKTIVE STEČAJNIH UPRAVITELJA I STRUČNOG OSOBLJA KREDITNIH INSTITUCIJA U STEČAJU

\begin{tabular}{|l|c|c|c|c|}
\hline & $\begin{array}{c}\text { Procjena } \\
\text { parametara }\end{array}$ & $\begin{array}{c}\text { Standardna } \\
\text { pogreška }\end{array}$ & t vrijednost & p vrijednost \\
\hline Intercept & 2,506874669 & 1,101190747 & 2,276512654 & 0,03163971 \\
\hline $\mathrm{X}$ & 0,09281438 & 0,05421036 & 1,71211518 & 0,001574842 \\
\hline
\end{tabular}

Izvor: Istraživanje autora rada 
Testiranje se provodi uz razinu signifikantnosti $\alpha=0,05(5 \%)$ i tada je za $\mathrm{n}=$ 27 (broj učitanih opažanja), $\mathrm{t}_{\alpha}(\mathrm{n}-2)=\mathrm{t}_{0,05}(25)=1,70$. Test veličina ( $\mathrm{t}$ vrijednost) $\mathrm{u}$ konkretnom slučaju iznosi $t=\beta$ /standardna pogreška $(\beta)=0,09281438 / 0,05421036$ $=1,71211518$. Budući da je $\mathrm{t}>\mathrm{t}_{\alpha}(\mathrm{n}-2)$ proizlazi zaključak, da se $-\mathrm{uz}$ razinu signifikantnosti $5 \%$ - hipoteza H1 može prihvatiti. Odluka o ishodu testa mogla se donijeti i na temelju p vrijednosti. Budući da je p vrijednost u analizi manja od 0,05 hipoteza H1 može se prihvatiti.

Temeljem deskriptivne statistike i regresijske analize može se prihvatiti hipoteza HI da kvaliteta komuniciranja eksternih revizora s upravljačkim strukturama kreditne institucije utječe na učinkovitost eksterne revizije i upravljačkih struktura.

Regresijskom analizom varijabli testirana je druga hipoteza prema kojoj kvaliteta komuniciranja eksternih revizora s revizijskim odborom kreditne institucije utječe na učinkovitost eksterne revizije i upravljačkih struktura, posebice nadzornog odbora. Primijenjen je t test na gornju granicu jer je pretpostavljen pozitivan smjer između nezavisne i zavisne varijable. Kao nezavisna varijabla definirana je kvaliteta komunikacije eksternih revizora s revizijskim odborom kreditne institucije, dok je zavisna varijabla učinkovitost eksterne revizije i upravljačkih struktura. Zasebno je provedena regresijska analiza podataka prikupljenih od svih ispitanika.

Tablica 14.
REZULTATI REGRESIJSKE ANALIZE UTJECAJA KVALITETE KOMUNICIRANJA EKSTERNIH REVIZORA S REVIZIJSKIM ODBOROM NA UČINKOVITOST EKSTERNE REVIZIJE I UPRAVLJAČKIH STRUKTURA, POSEBICE NADZORNOG ODBORA, IZ PERSPEKTIVE EKSTERNIH REVIZORA KOJI OBAVLJAJU ILI SU OBAVLJALI REVIZIJU GODIŠNJIH FINANCIJSKIH IZVJEŠTAJA KREDITNIH INSTITUCIJA

\begin{tabular}{|l|c|c|c|c|}
\hline & $\begin{array}{c}\text { Procjena } \\
\text { parametara }\end{array}$ & $\begin{array}{c}\text { Standardna } \\
\text { pogreška }\end{array}$ & t vrijednost & p vrijednost \\
\hline Intercept & 2,398381868 & 0,670112298 & 3,579074544 & 0,000777964 \\
\hline $\mathrm{X}$ & 0,070322241 & 0,031243494 & 2,250780312 & 0,028827913 \\
\hline
\end{tabular}

Izvor: Istraživanje autora rada

Testiranje se provodi uz razinu signifikantnosti $\alpha=0,05(5 \%)$ i tada je za $n=52$ (broj učitanih opažanja), $\mathrm{t}_{\alpha}(\mathrm{n}-2)=\mathrm{t}_{0,05}(50)=2,01$. Test veličina ( $\mathrm{t}$ vrijednost) $\mathrm{u}$ konkretnom slučaju iznosi $t=\beta$ /standardna pogreška $(\beta)=0,070322241 / 0,031243494$ $=2,250780312$. Budući da je $\mathrm{t}>\mathrm{t}_{\alpha}(\mathrm{n}-2)$ proizlazi zaključak, da se $-\mathrm{uz}$ razinu signifikantnosti $5 \%$ - hipoteza $\mathrm{H} 2$ može prihvatiti. Odluka o ishodu testa mogla 
se donijeti i na temelju p vrijednosti. Budući da je p vrijednost u analizi manja od 0,05 hipoteza $\mathrm{H} 2$ može se prihvatiti.

Tablica 15.

REZULTATI REGRESIJSKE ANALIZE UTJECAJA KVALITETE KOMUNICIRANJA EKSTERNIH REVIZORA S REVIZIJSKIM ODBOROM NA UČINKOVITOST EKSTERNE REVIZIJE I UPRAVLJAČKIH STRUKTURA, POSEBICE NADZORNOG ODBORA, IZ PERSPEKTIVE ČLANOVA UPRAVE I NADZORNOG ODBORA KREDITNIH INSTITUCIJA

\begin{tabular}{|l|c|c|c|c|}
\hline & $\begin{array}{c}\text { Procjena } \\
\text { parametara }\end{array}$ & $\begin{array}{c}\text { Standardna } \\
\text { pogreška }\end{array}$ & t vrijednost & p vrijednost \\
\hline Intercept & 1,177911306 & 0,850601368 & 1,384798273 & 0,172794373 \\
\hline$X$ & 0,116648161 & 0,032581662 & 3,580178374 & 0,000823663 \\
\hline
\end{tabular}

Izvor: Istraživanje autora rada

Testiranje se provodi uz razinu signifikantnosti $\alpha=0,05(5 \%)$ i tada je za $n=48$ (broj učitanih opažanja), $\mathrm{t}_{\alpha}(\mathrm{n}-2)=\mathrm{t}_{0,05}(46)=2,02$. Test veličina ( $\mathrm{t}$ vrijednost) $\mathrm{u}$ konkretnom slučaju iznosi $t=\beta /$ standardna pogreška $(\beta)=0,116648161 / 0,032581662$ $=3,580178374$. Budući da je $\mathrm{t}>\mathrm{t}_{\alpha}(\mathrm{n}-2)$ proizlazi zaključak, da se $-\mathrm{uz}$ razinu signifikantnosti $5 \%$ - hipoteza $\mathrm{H} 2$ može prihvatiti. Odluka o ishodu testa mogla se donijeti i na temelju p vrijednosti. Budući da je $\mathrm{p}$ vrijednost $\mathrm{u}$ analizi manja od 0,05 hipoteza $\mathrm{H} 2$ može se prihvatiti.

Tablica 16.

REZULTATI REGRESIJSKE ANALIZE UTJECAJA KVALITETE KOMUNICIRANJA EKSTERNIH REVIZORA S REVIZIJSKIM ODBOROM

NA UČINKOVITOST EKSTERNE REVIZIJE I UPRAVLJAČKIH STRUKTURA, POSEBICE NADZORNOG ODBORA, IZ PERSPEKTIVE STEČAJNIH UPRAVITELJA I STRUČNOG OSOBLJA KREDITNIH INSTITUCIJA U STEČAJU

\begin{tabular}{|l|c|c|c|c|}
\hline & $\begin{array}{c}\text { Procjena } \\
\text { parametara }\end{array}$ & $\begin{array}{c}\text { Standardna } \\
\text { pogreška }\end{array}$ & t vrijednost & p vrijednost \\
\hline Intercept & 3,069539926 & 1,092441756 & 2,809797327 & 0,009488964 \\
\hline $\mathrm{X}$ & 0,08999775 & 0,03377966 & 2,66425861 & 0,000396927 \\
\hline
\end{tabular}

Izvor: Istraživanje autora rada 
Testiranje se provodi uz razinu signifikantnosti $\alpha=0,05(5 \%)$ i tada je za $\mathrm{n}=$ 27 (broj učitanih opažanja), $\mathrm{t}_{\alpha}(\mathrm{n}-2)=\mathrm{t}_{0,05}(25)=1,70$. Test veličina ( $\mathrm{t}$ vrijednost) $\mathrm{u}$ konkretnom slučaju iznosi $\mathrm{t}=\beta /$ standardna pogreška $(\beta)=0,08999775 / 0,03377966$ $=2,66425861$. Budući da je $\mathrm{t}>\mathrm{t}_{\alpha}(\mathrm{n}-2)$ proizlazi zaključak, da se - uz razinu signifikantnosti $5 \%$ - hipoteza $\mathrm{H} 2$ može prihvatiti. Odluka o ishodu testa mogla se donijeti i na temelju $\mathrm{p}$ vrijednosti. Budući da je $\mathrm{p}$ vrijednost $\mathrm{u}$ analizi manja od 0,05 hipoteza $\mathrm{H} 2$ može se prihvatiti.

Temeljem deskriptivne statistike i regresijske analize može se prihvatiti hipoteza $\mathrm{H} 2$ da kvaliteta komuniciranja eksternih revizora s revizijskim odborom kreditne institucije utječe na učinkovitost eksterne revizije i upravljačkih struktura, posebice nadzornog odbora.

Prije prikaza rezultata korelacijske analize kojom je testirana hipoteza $\mathrm{H} 3$, prikazana je komparacija rezultata vrijednosti aritmetičkih sredina za varijablu povezanost neučinkovitosti eksterne revizije s razvojem nepoželjnog scenarija koji uključuje i otvaranje stečaja nad kreditnom institucijom.

Tablica 17.

\section{KOMPARACIJA REZULTATA ARITMETIČKE SREDINE POVEZANOSTI NEUČINKOVITOSTI EKSTERNE REVIZIJE S RAZVOJEM NEPOŽELJNOG SCENARIJA KOJI UKLJUČUJE I OTVARANJE STEČAJA NAD KREDITNOM INSTITUCIJOM}

\begin{tabular}{|l|c|c|c|}
\hline & $\begin{array}{c}\text { Perspektiva eksternih } \\
\text { revizora koji obavljaju } \\
\text { ili su obavljali reviziju } \\
\text { godišnjih financijskih } \\
\text { izvještaja kreditnih } \\
\text { institucija }\end{array}$ & $\begin{array}{c}\text { Perspektiva članova } \\
\text { uprave i nadzornih } \\
\text { odbora kreditnih } \\
\text { institucija }\end{array}$ & $\begin{array}{c}\text { Perspektiva stečajnih } \\
\text { upravitelja i stručnog } \\
\text { osoblja kreditnih } \\
\text { institucija u stečaju }\end{array}$ \\
\hline $\begin{array}{l}\text { Povezanost neučinkovitosti } \\
\text { eksterne revizije s razvojem } \\
\text { nepoželjnog poslovnog scenarija } \\
\text { koji uključuje i otvaranje stečaja } \\
\text { nad kreditnom institucijom }\end{array}$ & 3,52 & 4,19 & 3,70 \\
\hline
\end{tabular}

Izvor: Istraživanje autora rada

Evidentno je kako članovi uprave i nadzornog odbora kreditnih institucija smatraju povezanost neučinkovitosti eksterne revizije s razvojem nepoželjnog poslovnog scenarija koji uključuje i otvaranje stečaja nad kreditnom institucijom jačom nego što to smatraju ostali ispitanici. 
Tablica 18.

KENDALL KORELACIJA ZA HIPOTEZU H3

\begin{tabular}{|c|c|c|c|c|c|}
\hline & & & $\begin{array}{l}\text { Perspektiva } \\
\text { članova } \\
\text { uprave i } \\
\text { nadzornog } \\
\text { odbora } \\
\text { kreditnih } \\
\text { institucija }\end{array}$ & $\begin{array}{l}\text { Perspektiva } \\
\text { eksternih } \\
\text { revizora koji } \\
\text { obavljaju ili } \\
\text { su obavljali } \\
\text { reviziju } \\
\text { godišnjih } \\
\text { financijskih } \\
\text { izvještaja } \\
\text { kreditnih } \\
\text { institucija }\end{array}$ & $\begin{array}{l}\text { Perspektiva } \\
\text { stečajnih } \\
\text { upravitelja } \\
\text { i stručnog } \\
\text { osoblja } \\
\text { kreditnih } \\
\text { institucija u } \\
\text { stečaju }\end{array}$ \\
\hline \multirow{9}{*}{ Kendall's } & \multirow{3}{*}{$\begin{array}{l}\text { Perspektiva članova } \\
\text { uprave i nadzornog odbora } \\
\text { kreditnih institucija }\end{array}$} & Koeficijent korelacije & 1,000 & 057 & $0,276^{*}$ \\
\hline & & Sig. (1-tailed) & & ,389 & 039 \\
\hline & & & & & \\
\hline & \multirow{3}{*}{$\begin{array}{l}\text { Perspektiva eksternih } \\
\text { revizora koji obavljaju ili su } \\
\text { obavljali reviziju godišnjih } \\
\text { financijskih izvještaja } \\
\text { kreditnih institucija }\end{array}$} & Koeficijent korelacije & 057 & 1,000 &, 115 \\
\hline & & Sig. (1-tailed) &, 389 & & 285 \\
\hline & & & & & \\
\hline & \multirow{3}{*}{$\begin{array}{l}\text { Perspektiva stečajnih } \\
\text { upravitelja i stručnog } \\
\text { osoblja kreditnih institucija } \\
\text { u stečaju }\end{array}$} & Koeficijent korelacije & $0,276^{*}$ & ,115 & 1,000 \\
\hline & & Sig. (1-tailed) & ,039 & 285 & \\
\hline & & & & & \\
\hline
\end{tabular}

* korelacija je signifikantna uz razinu značajnosti 0,05

Izvor: Istraživanje autora rada

Prema rezultatima Kendall korelacijske analize perspektiva članova uprave i nadzornog odbora kreditnih institucija, vezano uz povezanost neučinkovitosti eksterne revizije s razvojem nepoželjnog poslovnog scenarija koji uključuje i otvaranje stečaja nad kreditnom institucijom, u korelaciji je s perspektivom stečajnih upravitelja i stručnog osoblja kreditnih institucija. Korelacija je signifikantna uz razinu značajnosti 0,05 i iznosi 0,276.

Temeljem rezultata deskriptivne statistike i korelacijske analize može se prihvatiti hipoteza $\mathrm{H} 3$ da je neučinkovitost eksterne revizije povezana s otvaranjem stečajeva nad dijelom kreditnih institucija . 


\section{ZAKLJUČAK}

Testiranjem predloženog komunikacijskog modela odnosa eksternih revizora i upravljačkih struktura utvrđeno je kako se svi ispitanici (eksterni revizori koji obavljaju ili su obavljali reviziju godišnjih financijskih izvještaja kreditnih institucija, članovi uprave i nadzornog odbora kreditnih institucija te stečajni upravitelji i stručno osoblje u kreditnim institucijama u stečaju) slažu kako model jako pridonosi boljem radu eksterne revizije, s jedne strane, te upravljačkih struktura kreditne institucije, s druge strane. Rezultati ovoga rada konzistentni su s rezultatima drugih istraživanja. Tako, slično Colbertovim zaključcima iz 2002., oblikovani model odnosa eksternih revizora i upravljačkih struktura kreditne institucije eksterne revizore promatra kao važnu podršku povećanju učinkovitosti upravljačkih struktura kreditnih institucija. Nadalje, zaključci rada su također u skladu s rezultatima istraživanja Cohena i suradnika iz 2007., i to u onom dijelu u kojem se potvrđuje kako komunikacija revizora s upravljačkim strukturama može imati utjecaj, među ostalim, i na učinkovitost rada eksternog revizora.

Zaključno je važno apostrofirati kako su ostvareni ciljevi rada te kako su prihvaćene hipoteze istraživanja. S obzirom na to da je komuniciranje eksternih revizora i upravljačkih struktura kreditnih institucija još uvijek nedovoljno istraživano, rezultati rada svakako pridonose obogaćivanju znanstvenih spoznaja, ali također imaju vrlo vrijedan aplikativan doprinos koji seže znatno dalje i više od analiziranih kreditnih institucija.

Kao ograničenja pri provedbi ovoga istraživanja mogu se izdvojiti veći broj skupina koje je anketnim upitnikom trebalo ispitati, otežanost dobivanja odgovora od ispitanika i subjektivnost ispitanika. Veći broj skupina ispitanika predstavlja sugestiju za buduće istraživanje. Tu se ponajprije misli na stečajne upravitelje i stručno osoblje kreditnih institucija koje su zaključile stečajni postupak, ali i na članove uprava odnosno nadzornih odbora onih kreditnih institucija nad kojima je pokrenut stečajni postupak. Zatim, uključivanjem kreditnih institucija u likvidaciji također bi se povećao uzorak istraživanja jer bi se u istraživanje uključili likvidatori i stručno osoblje kreditnih institucija nad kojima je pokrenut likvidacijski postupak. Slično kao kod kreditnih institucija u stečaju, istraživanje bi se moglo provoditi anketiranjem i članova uprava odnosno nadzornih odbora onih kreditnih institucija nad ko-

jima je pokrenut likvidacijski postupak. Uključivanje navedenih skupina ispitanika moglo bi se smatrati poželjnim smjernicama budućih istraživanja. 


\section{LITERATURA}

1. Barbić, J. (2007). Pravo društava - knjiga druga-društva kapitala - četvrto izdanje. Zagreb: Organizator.

2. Basu S. (2007) The Role of Financial Institutions in the Context of Economic Development. In: McCombie J., González C.R. (eds) Issues in Finance and Monetary Policy. Palgrave Macmillan, London, str. 171-189.

3. Cohen, J., Gaynor, L. M., Krishnamoorthy, G., Wright, A. M. (2007). Auditor Communications with the Audit Committee and the Board of Directors: Policy Recommendations and Opportunities for Future Research. Accounting Horizons. Vol. 21(2), str. 165-187.

4. Colbert, J. L. (2002). Corporate governance: communications from internal and external auditors. Managerial Auditing Journal, Vol. 17(3), str. 147-152.

5. Filipović, I., Bartulović, M., Filipović, M. (2018). Revizija - mehanizam nadzora i povjerenja. Split: Redak.

6. Ghafran, C., O'Sullivan, N. (2013). The Governance Role of Audit Committees: Reviewing a Decade of Evidence. International Journal of Management Reviews. Vol. 15(4), str. 381-407.

7. Gorenc, V, Ćesić, Z., Buljan, V., Brkanić, V. (2008). Komentar Zakona o trgovačkim društvima. Zagreb: RRiF-plus d.o.o. za nakladništvo i poslovne usluge.

8. Gras-Gil, E., Marin-Hernandez, S., Garcia-Perez de Lema, D. (2012). Internal audit and financial reporting in the Spanish banking industry. Managerial Auditing Journal. Vol. 27(8), str. 728-753.

9. Haron, H., Chambers, A., Ramsi, R., Ismail, I. (2004). The reliance of external auditors on internal auditors. Managerial Auditing Journal. Vol. 19(9), str. 1148-1159.

10. Hrvatska revizorska komora, Međunarodni revizijski standardi. Raspoloživo na: http://www.revizorska-komora.hr/index.php/kodeks-standardi-smjernice/ medjunarodni-revizijski-standardi.html [pristupljeno: 20. siječnja 2019.].

11. Husnin, A. I., Nawawi, A., Salin, A. S. A. P. (2016). Corporate governance and auditor quality - Malaysian evidence. Asian Review of Accounting. Vol. 24(2), str. 202-230.

12. Jurić, D. (2013) Politika primitaka u kreditnim institucijama u europskom i hrvatskom pravu. Zbornik Pravnog fakulteta Sveučilišta u Rijeci, Vol. 34(1), str. 359-391. 
M. FILIPOVIĆ: Istraživanje odnosa upravljačkih struktura i eksterne revizije u korporativnom upravljanju EKONOMSKI PREGLED, 72 (4) 522-549 (2021)

13. Međunarodni revizijski standardi, Međunarodni standardi kontrole kvalitete, Međunarodne smjernice revizijske prakse (2010) - prijevod s engleskog jezika. Hrvatska revizorska komora, Zagreb.

14. Mlikotin-Tomić, D., Momčinović, H., Gverić, A., Spajić, F., Gulin, D., Spremić, I. (1994). Zakon o trgovačkim društvima i pravno ekonomski aspekti njegove primjene. Zagreb: Hrvatska zajednica računovođa i financijskih djelatnika.

15. Tipurić, D. (2006). Nadzorni odbor i korporativno upravljanje. Zagreb: Sinergija.

16. Tušek, B., Filipović, D., Pokrovac, I. (2008) Uloga revizijskog odbora u povećanju efikasnosti eksternih i internih mehanizama korporativnog upravljanja. Zbornik Ekonomskog fakulteta u Zagrebu, Vol. 6(1), str. 223-240.

17. Tušek, B., Filipović, I., Filipović, D. (2009) Istraživanje odnosa eksterne revizije i nadzornog odbora u Republici Hrvatskoj. Zbornik Ekonomskog fakulteta u Zagrebu, Vol. 7(1), str. 121-141.

\section{RESEARCH ON THE RELATIONSHIP BETWEEN GOVERNANCE STRUCTURES AND EXTERNAL AUDIT IN CORPORATE GOVERNANCE

\author{
Summary
}

Quality communication of external auditors with governance structures is of paramount importance for the efficient operation of credit institutions. Therefore, the question arises as to whether the formation of a model for the relationship of external auditors and the governance structures of a credit institution can enhance the work of an external audit, on the one hand, and the governance structures of a credit institution, on the other. The contribution of this research is: an analysis of the quality of external auditors' communication with the credit institution's governance structures and the impact of the quality of these relationships on the effectiveness of external audit and governance structures; an analysis of the quality of external auditors' communication with the credit institution's audit committee and the impact of the quality of those relationships on the effectiveness of the external audit and governance structures, in particular the supervisory board; identifying whether external audit inefficiencies are related to the opening of bankruptcies of credit institutions and determining whether the proposed model of relations between the external auditors and the credit institution's governance structures contributes to the better work of the external audit and to the better functioning of the credit institution's governance structures. The survey, conducted in the Republic of Croatia, involved external auditors that are or were auditing the annual financial statements of credit institutions, members of the management and supervisory boards of credit institutions, and insolvency office holders and professional staff of credit institutions in bankruptcy. The results of the empirical study confirm that the tested communication model contributes to a more efficient operation of the credit institution's external audit and governance structures. tions

Key words: quality communication, external auditors, governance structures, credit institu- 